\title{
Development of Digital Skills and Engineering Thinking in Students as Part of the Digital Summer Project
}

\author{
https://doi.org/10.3991/ijep.v11i2.17215 \\ Tatyana Anisimova ( $\left.{ }^{\varpi}\right)$, Aigul Ganeeva, Landysh Sharafeeva \\ Elabuga Institute of Kazan Federal University, Elabuga, Russian Federation \\ anistat@mail.ru
}

\begin{abstract}
Digitalization of the economy is a key priority for Russia today, which makes the problem stated herein relevant. Personal motivations, values, morals, and ethics are of increasing importance. In this regard, project, flexible, and soft skills are coming to the fore; these include digital skills such as the ability to confidently, effectively, critically, and safely pick and apply information and communication technologies in various aspects of life. Research and experimentation skills, being an integral part of engineering culture and thinking, stay relevant, too. The purpose of the study is to prove the effectiveness of developing digital competencies and engineering thinking in children and young people during the Digital Summer project, developed as part of a grant for conducting thematic sessions in advanced areas of discrete mathematics, informatics, and digital technologies. In the course of the study, effectiveness was assessed by mathematical processing of the results of questionnaires and surveys of session participants. The results of the study allow concluding that it is possible to translate the experience gained into the system of working with children and youth.
\end{abstract}

Keywords-Digital economy, thematic sessions, digital skills, engineering thinking, discrete mathematics.

\section{Introduction}

In 2017, the Government of the Russian Federation approved the Digital Economy of the Russian Federation Program; Human Resources for the Digital Economy is one of the five baseline areas of the program [1]. The Government recognizes that the country lacks human resources for the digital economy, while the existing educational programs do not meet its needs. The digital economy alters human activity. Communication, management, and the creative skills of an actor are becoming key. The transition alters the worldview, role, and capacities of a person in a variety of activities [2]. New activities emerge, and new technologies change the instrumental capabilities of the actor [3; 4]. Personal motivations, values, morals, and ethics are of increasing importance.

The review of the literature on the research problem will rely on the recommendations set out in the work $[5 ; 6]$. 
The problem raised by the authors of the article consists of two key components: digital competencies and engineering thinking. After analyzing the analytical report of the Sberbank Corporate University and considering the European model of digital competencies for education, it can be stated that digital competencies mean the following:

- The ability to solve various problems in the use of information and communication technologies

- The ability to use and create content using digital technologies, including searching and sharing information, answering questions, interacting with other people

- The capacity for digital collaboration, security, and problem-solving.

Despite the massive introduction of information and communication technologies and the increasing number of Internet users, students are in dire need of education in the field of digital technologies, in the formation of digital competencies. This conclusion was made by the authors based on the analysis of the work by Soldatova, dedicated to the results of the first all-Russian study of the digital competence of adolescents and parents. This work shows that every fifth child would like, first, to undergo a special training program on the Internet, and second, to improve their digital competence [7].

As is known, engineering thinking is a special type of professional thinking that is formed and manifested in the ability to independently navigate new technologies, in their rationalization, modernization, and implementation in production.

In their research, the authors rely on the model [8], according to which engineering thinking includes the following components: technical (the ability to analyze the composition, structure, arrangement, and principle of operation of technical objects in changed conditions), constructive (construction a certain model of solving the problem or task), research (defining the novelty of the task, the ability to compare it with the known classes of tasks, the ability to justify one's actions, the results obtained and draw conclusions) and economic (reflection of the quality of the process and the result of activity from the standpoint of market requirements).

In the spring of 2019, the Ministry of Education of the Russian Federation announced a contest for grants for the Organization of Thematic Sessions at Schoolchildren Summer Camps in Advanced Discrete Mathematics, Informatics, and Digital Technology under the Human Resources for the Digital Economy, a Federal Project under the National Digital Economy Program of the State Program for Development of Education.

The contest sought to [9]:

a) Enable the identification, support, and furtherance of talents in discrete mathematics, informatics, and digital technology to develop the digital economy;

b) Support the best practices of organizing and conducting training sessions on various topics in discrete mathematics, informatics, and technologies related to relevant problems of the digital economy on the ground of summer camps run by educational organizations that provide recreation and recovery services for children. 
Teachers of the Yelabuga Institute, Kazan Federal University (YI KFU) submitted their Digital Summer project for the grant. The Project was designed to create digital skills and engineering thinking in talented schoolchildren so as to make them more competitive in a digital economy; to transfer IT tools to a variety of applications; to boost the digital literacy of schoolchildren; to create an educational foundation for the world of future professions in the digital society and economy of today.

When developing the project, the authors based their ideas on the assumption that it is communication or gaming activity rather than education per se that plays a key role in developing digital competence and engineering skills.

As a result of the contest, the Digital Summer Project was one of the winners of the aforesaid grant and took place in July and August 2019 at the Yelabuga Institute of KFU.

Let us consider the key points of the project and evaluate its effectiveness in the formation of digital competencies and engineering thinking in children and young people.

\section{Description and Implementation of the Project}

As part of the Project, YI KFU organized three thematic sessions: Territory of Digital Security, Digital Russia and Professions of the Future, and Science Mix. During the thematic sessions at the summer camp, the University's teachers tested learning technologies of their own development, which were intended to boost skills in digital technology and engineering literacy.

The programs were based on the YI KFU teachers' experiences presented in [10; 11].

They also drew upon the experience of Russian and international researchers. For example, the development of the project was based on training programs aimed at improving children's mathematical skills, proposed in the work by the following researchers [12-21].

The Digital Summer Project focuses on professions of the future and implies not only educating children and their parents about advanced skills but also acquiring such skills in practice, whether individually or in teams, using state-of-the-art laboratory equipment and various digital technologies.

Compared to a traditional laboratory, a digital one enables faster, more accurate and visual experimentation, as it opens up virtually limitless opportunities for data processing and analysis and expands the research component in sciences. Digital labs are mobile and suitable for indoor and field laboratory sessions [22].

A digital lab can be used to solve interdisciplinary problems, master the concepts and methods of mathematics and IT [23], to learn more about related educational areas: IT, mathematical functions and graphs, mathematical processing of experimental data, statistics, approximate calculations, etc.

The use of various digital laboratories as next-generation facilities has been covered by many researchers. Some dwell upon their application in research projects of ecology students [24-26]. Others discuss the use of digital laboratories in science classes, as well as organizing students' learning of digital tools [27; 28]. 
Physicists are interested in digital laboratories as a tool for mockup experiments at secondary schools [29-31].

Summer camp attendees made active use of digital labs during sessions. Let us talk of them briefly.

The Computer Science Lab was used to help schoolchildren to design computer, local, and global network architecture by utilizing sets of specialized equipment.

Teachers of the Digital Competence Lab enabled schoolchildren to gain hands-on experience in digital tech while also teaching them about the prospects of digital tech development in the digital economy.

The RoboStARt Lab was designed to boost schoolchildren's thinking in robotics, to develop their research skills fundamental to researchers and engineers.

The Digital Physics Lab enabled the participants to study the physical foundations of digital tech and the basics of data registration and digital process, as well as to process the results of experiments in physics and digital economics.

Classes in the 3D Design Lab boosted creative thinking and helped to acquire the design and engineering skills for treatment, conversion, and creation of textiles, plastic, and wood products using digital equipment.

The Digital Mathematics Lab was designed to teach the foundations of math to help children to further their digital literacy. Learning mathematical concepts in unity with their applied interpretation, coupled with mathematical modeling of real-world processes, laid the foundations for further development of engineering thinking. This paper will consider the latter lab in detail as of all academic competencies, math is recognized as an important skill for international leadership and for any job in research or technology.

Discrete mathematics is a discipline that studies discrete mathematical structures such as graphs or logic statements [32]. It has a wide range of applications: electronics, computer science, optimization and decision-making, etc. [33]. Various sections of discrete mathematics offer a broad range of opportunities to further one's engineering thinking. When studying discrete mathematics, students not only acquire new knowledge and skills for using it but also develop flexible and systematic thinking, as well as the ability to analyze, synthesize, and abstract.

For the Digital Summer Project, discrete mathematics was taught in two modules: (1) Graphs, and (2) Logic.

Let us consider in more detail the content and teaching methods of Module I. Graphs are used to visualize objects and their relations. They can be used to image data of any complexity and help to solve more complicated problems. Graph-based data visualization provides greater flexibility and a different interesting view of the problem. Classes of the discrete mathematics project were practice-oriented. The theory was taught interactively using multimedia resources. The following concepts of the graph theory were taught: graph, graph vertex, graph edge, undirected graph, graph vertex degree, loop, route, chain, cycle, connectivity, connectivity components, tree, directed tree, root, level, tree branch and leaf, binary tree, weighted graph, and network. Interactive teaching methods were applied in the class to emphasize schoolchildren's activities, motivation, communication skills, and teamwork skills. The children were split into groups of two, and each such subgroup would get a problem or two to solve on their own. After a fixed timeframe, they would present and explain the solution. At the end of the class, the subgroups evaluated each other. The proce- 
dure is great for team building as it gives a sense of belonging and develops personal qualities.

The focus was made on using graph visualization environments to visualize algorithms and speed up graph plotting and processing. To that end, the authors used Grafoanalizator, free software for graph visualization and processing [34]. This software can be used not only to create and process graphs but also to visualize algorithm output [35]. In the class, schoolchildren were tasked to do such things as finding the shortest path, assigning responsibilities to team members, etc. For instance, students were tasked to find the shortest Yelabuga-Moscow path. The teacher showed several alternative routes. First, the children used the Internet to find the actual distance between the two cities. To visualize the problem, they added vertices (cities) and weighted edges (i.e. with assigned path length) to the program. The edge weight was added automatically to the adjacency matrix. The software can apply multiple algorithms to solve such problems: Dijkstra, Ford-Bellman, Floyd-Warshall, etc. The vertices of the shortest path are in bold, see Figure 1.

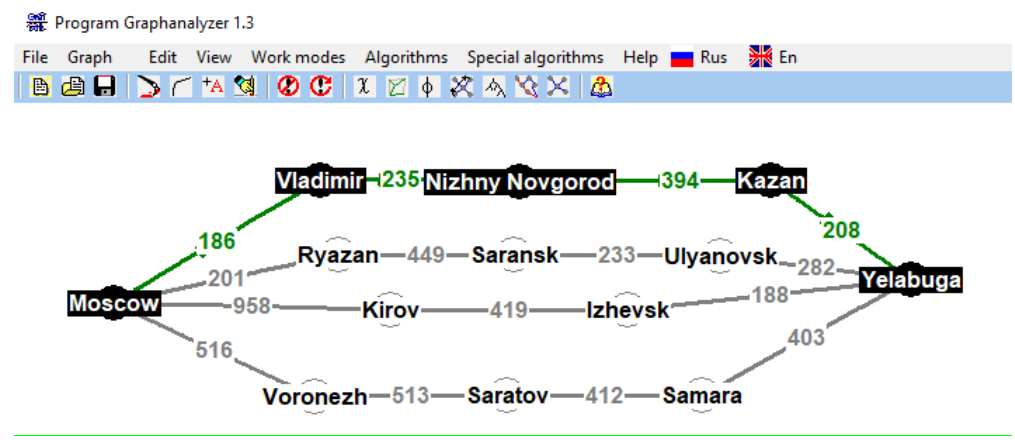

Fig. 1. Finding the shortest Moscow-Yelabuga path

The case showed that children were happy to use Grafoanalizator to simulate problems, to actively discuss the algorithm outputs; they were quick learners.

Discrete mathematics is at the junction of mathematics and computer science. One who knows the fundamentals of graph-based modeling can not only solve problems in these two disciplines but also find the relations between the data and the unknown in a variety of real-world situations; the approach implies a gradual increase in the complexity of such situations.

The acquired knowledge and skills in discrete mathematics facilitate the furtherance of logical thinking and help students to master the skills of self-education while also learning how to apply IT to a variety of problems, study their curricular disciplines more profoundly, and improve communication, digital, and engineering thinking skills.

\section{$3 \quad$ Materials and Methods}

In implementing the thematic sessions of the TsifroLeto (Digital Summer) project, the main methods for identifying the effectiveness of the formation of digital compe- 
tencies and engineering thinking in children and young people were interviews, questionnaires, assessment of the products of creative activity, conversations, observation using diagnostic cards, solving project problems, case assignments, educational tasks, projects and project assignments, web-quests, defense of project-research works, portfolios, etc.

The questionnaire was answered by 102 participants of the Science Mix session (Session 3: mathematics, computer science, and physics) aged 11-18 before and after the session. The children were asked to rate their knowledge and skills 1 to 10 by the following criteria:

1. I know various Internet search engines for searching information, music, photos, and videos.

2. I know various mobile apps and what they can be used for

3. I know the basics of mathematical modeling of real-world objects

4. I can use special settings (operators) of search engines to find specific results

5 . I can utilize social media for learning

6. I can work in a team

7. I am able to create mathematical models for digital reality

8. I am able to create digital resources

9. I am familiar with high-tech professions for the digital economy

10. I am able to apply knowledge of discrete mathematics to solve real problems by means of IT tools

The authors of the Project also surveyed children and their parents to identify what success that they had at the Digital Summer camp they deemed most important. The respondents were asked multiple-choice questions.

\section{$4 \quad$ Results}

To complete the research, the authors analyzed the responses of Session 3 participants to the questionnaire above. This format was intended to compare the expected and actual outcomes of the sessions.

Let us describe some of the results, see Figs. 2 and 3. The results were referred to as the First and Final ones.

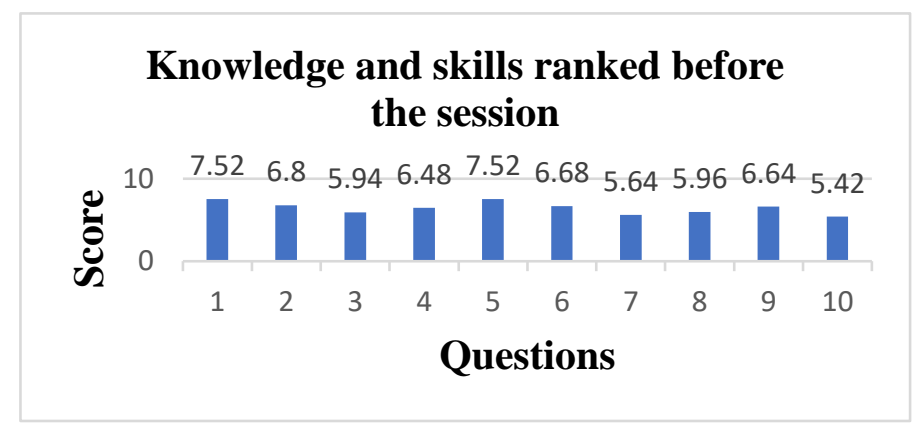

Fig. 2. First results 


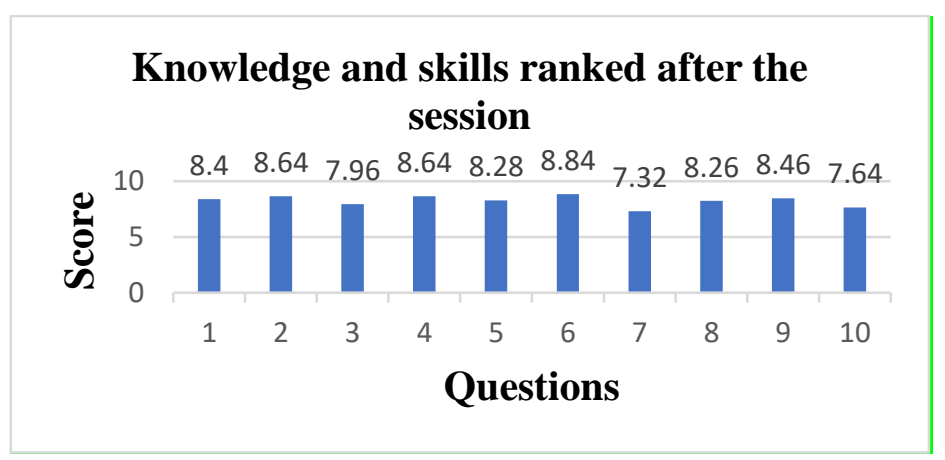

Fig. 3. Final results

To determine the effectiveness of the formation of digital competencies and engineering thinking in children and young people during the implementation of the Digital Summer Project, the Student's t-test method was used. In our case, the sample is linked.

Table 1. Experimental results

\begin{tabular}{|c|c|c|c|c|}
\hline Questions & Score1 & Score2 & d & $\mathbf{d}^{\mathbf{2}}$ \\
\hline 1 & 7,52 & 8,4 & 0,88 & 0,7744 \\
\hline 2 & 6,8 & 8,64 & 1,84 & 3,3856 \\
\hline 3 & 5,94 & 7,96 & 2,02 & 4,0804 \\
\hline 4 & 6,48 & 8,64 & 2,16 & 4,6656 \\
\hline 5 & 7,52 & 8,28 & 0,76 & 0,5776 \\
\hline 6 & 6,68 & 8,84 & 2,16 & 4,6656 \\
\hline 7 & 5,64 & 7,32 & 1,68 & 2,8224 \\
\hline 8 & 5,96 & 8,26 & 2,3 & 5,29 \\
\hline 9 & 6,64 & 8,46 & 1,82 & 3,3124 \\
\hline 10 & 5,42 & 7,64 & 2,22 & 4,9284 \\
\hline Sum & 64,6 & 82,44 & 17,84 & 34,5024 \\
\hline Average & 6,46 & 8,244 & & \\
\hline
\end{tabular}

Let's find the average of the differences Score1 and Score2:

$$
\bar{d}=\frac{\sum_{i=1}^{n} d_{i}}{n}=\frac{17,84}{10}=1,784
$$

Let's find Sd:

$$
S d=\sqrt{\frac{\sum d_{i}^{2}-\frac{\left(\sum d_{i}\right)^{2}}{n}}{n(n-1)}}=\sqrt{\frac{34,5024-(21,76 * 21,76) / 10}{10 * 9}}=0,1723
$$

We get the value of $t$ :

$$
t_{\text {экс }}=\frac{\bar{d}}{S d}=\frac{1,784}{0,1723}=10,4
$$


The number of degrees of freedom: $\mathrm{k}=10-1=9$ and according to the table of critical values of the Student's t-criterion we find tcrit $=4.781$, experimental $t=10.4$, from which the conclusion is drawn - the children did notice an improvement in the knowledge and skills the program was tailored to boost: digital skills, engineering thinking, and communication skills.

For the final stage, the children also presented and defended their projects that were similar to or had the format of complete $R \& D$ projects. Some of the results are shown in Table 1.

Table 2. Projects of the Digital Summer participants

\begin{tabular}{|c|c|}
\hline $\begin{array}{c}\text { Laboratory / } \\
\text { area }\end{array}$ & Project topics \\
\hline Digital projects & $\begin{array}{l}\text { 1. Digital environment for development at an educational institution. } \\
\text { 2. Digital learning environment of the school. } \\
\text { 3. Digital class. } \\
\text { 4. Digital safety and security of schoolchildren. } \\
\text { 5. Professions of the digital society. } \\
\text { 6. Masterpieces of fine art in a digital format. } \\
\text { 7. Digital collage in arts. } \\
\text { 8. Collage thinking: from an idea to a product. } \\
\text { 9. Integration of collage art in the traditional artistic environment. } \\
\text { 10. Using digital technologies to develop art objects. }\end{array}$ \\
\hline Digital Mathematics & $\begin{array}{l}\text { Polyhedron section plotting. } \\
\text { Euler's topological theorem. } \\
\text { Applications of the derivative in practice. } \\
\text { Riddles of the pyramids. } \\
\text { Golden section around us. } \\
\text { How to measure the Earth? } \\
\text { Surface area of a globe. } \\
\text { Mathematicians from your area. } \\
\text { Symmetry around us. } \\
\text { Percent in real life. } \\
\text { Numeral systems. } \\
\text { Fibonacci numbers. } \\
\text { Fractals. } \\
\text { Plotting with a ruler and a compass. }\end{array}$ \\
\hline 3D modeling & $\begin{array}{l}\text { The program allows the participants to learn and practice 3D modeling for } \\
\text { further design and implementation of their projects by means of prototyping } \\
\text { technologies. }\end{array}$ \\
\hline
\end{tabular}

The teaching staff surveyed the children and their parents to find what they thought was the most important result of taking the Digital Summer course; most of the surveyed persons noted "gaining new knowledge and opportunities", "making new friends and expanding the social circle", and "furtherance of digital skills".

The parents mentioned that their children acquired knowledge and skills that would be important in life, as well as practical digital skills they were not taught in school; the children were able to show and develop their talents and creativity, to build selfconfidence. In general, surveying proved that the parents were happy with the program, that the program lived up to their expectations. 


\section{Discussion}

The organization of mathematical sessions was researched by many Russian and international scientists. In particular, [16] developed a program where trained mentors helped children to improve their mathematical skills by splitting children into small groups and adding such strategies as modeling, thinking out loud, practices, and error correction to the curriculum. Their results showed a considerable improvement in the children's mathematical skills and accomplishments. The study [15] expanded the children's knowledge of math by applying three training strategies: classroom studies that teachers added to the mathematics curriculum; teachers' training sessions to help them better understand the improvement of the children's mathematical skills and to interfere optimally; and math classes at home involving both children and their parents.

Math Island is a gamified math learning environment that adds construction management game mechanics to the roadmap of the basic mathematical curriculum; it is proposed in [36]. The papers $[37 ; 38]$ prove that integrating e-learning in a resourcebased learning method does improve the mathematical creative thinking and selfconfidence compared to learning without learning.

Vodopyan tells about the capabilities and applications of a computer laboratory from Philip Harris (the United Kingdom) for secondary-school science classes [39].

The organization of mathematical sessions for younger adolescents is an issue raised by [40; 41; 42]. [41] discuss in detail complementary mathematical training for children that can be provided during holidays by organizing specialized camps at a federal, regional, or municipal level. They refined a system of math classes for summer camp vacationers and described the structural components of the system: the target (the goals of the math classes designed for educational summer camps), the content (the contents of math classes), the procedural component (the teaching methods, tools, and formats), and the results (the outcomes of studies).

Let us note the features of the project. The children were given an opportunity to study the basics of 3D modeling, to raise their digital skills, to master a variety of digital tools and web technologies, to learn discrete mathematics and programming, to familiarize themselves with the psychology of Internet-based communications, to gain control over their emotions, and to gain teamwork skills, all in an entertaining fashion. Experienced university teachers taught schoolchildren to solve unordinary integrated problems and quests following the roadmap from training to project development.

The implementation of the TsifroLeto project was carried out with the involvement of intellectual partners and partner enterprises, the main of which is the Alabuga Special Economic Zone. It is a perfect setting for starting major investment projects and advancing the infrastructures of the special economic zone, as Alabuga's enterprises make active use of cutting-edge technology. Another important partner was Kvantorium, a technology park for children in Naberezhnye Chelny. Kvantorium offers a novel format of advanced education for Grade 5 to 11 children with a penchant for engineering and research. 


\section{Conclusion}

After the completion of the project, measures were taken to prepare children for participation in federal final events from the list of Olympiads and intellectual and creative competitions aimed at developing intellectual and creative abilities.

The thematic sessions helped to select schoolchildren that were invited to participate in the International Case Championship of the Youth Innovation Campus in October 2019. The tournament brought together $\sim 300$ alumni of regional Campuses from across the country. The Digital Summer participants were among the 35 best teams of the International Case Championship of the Youth Innovation Campus, where they developed creative solutions in areas relevant for Sevastopol's development: education, health, tourism, ecology, and adoption of cutting-edge technologies.

Also, the children were able to demonstrate all the experience accumulated during thematic sessions at the Interregional Olympiad for Schoolchildren in Mathematics "SAMMAT" and interregional subject Olympiads of Kazan Federal University, which are held in more than 20 subjects. These Olympiads are annually included in the list of Olympiads and other intellectual and creative competitions for Russian schoolchildren. These successes and the results of the research carried out confirm the effectiveness of the developed project in the formation of digital competencies and engineering thinking.

\section{$7 \quad$ References}

[1] The federal project "Personnel for the digital economy." URL: https://dataeconomy.ru/education (date of access: 21.01.2020).

[2] Anisimova, T. I., Sabirova, F. M., \& Shatunova, O. V. (2020). Formation of design and research competencies in future teachers in the framework of STEAM education. International Journal of Emerging Technologies in Learning, 15(2), 204-217. http://doi:10.3991/ijetv15i02.11537

[3] Gapsalamov, A. R., Bochkareva, T. N., Akhmetshin, E. M., Vasilev, V. L., Anisimova, T. I. (2020). Digital society: new challenges for education. Periodico tche quimica, 17(34), 803-816.

[4] Morales, D., Ruggiano, C., Carter, C., Pfeifer, K., \& Green, K. (2020). Disrupting to Sustain: Teacher Preparation Through Innovative Teaching and Learning Practices. Journal of Culture and Values in Education, 3(1), 1-20. https://doi.org/10.46303/jcve.03.01.1

[5] Brocke, J. vom, Simons, A., Niehaves, B., Niehaves, B., Reimer, K., Plattfaut, R., and Cleven, A., "Reconstructing the Giant: On the Importance of Rigour in Documenting the Literature Search Process" (2009). ECIS 2009 Proceedings. 161.

[6] Holik, I., \& Sanda, I. D. (2020). Character strengths and virtues of mentor teachers. International Journal of Engineering Pedagogy, 10(5), 7-19. https://doi.org/10.3991 lijep.v10i5.13709

[7] Soldatova G. U., Nestik T.A., Rasskazova E. I., \& Zotova E. Yu. (2013). Digital Competence of Russian Adolescents and Parents: Results of the All-Russian Study. Foundation for Internet Development, Moscow, 144 p. 
[8] Rakhmankulova G.A., Kuzmin S.Yu., Mustafina D.A., \& Rebro I.V. (2015). Development of Students' Engineering Thinking through Research Activity: Monograph. Publishing Solutions [Under license of Ridero]. $113 \mathrm{p}$.

[9] Competitive documentation URL: https://docs.edu.gov.ru/document/ 65ed7fa0e83fb35d250fdc57a632dbc6/download/1313/ (date of access 02.05.2019)

[10] Anisimova T.I., Latipova L.N., Sergeeva A.B., Sharafeeva L.R., \& Shatunova O.V. (2017). Formation of Teachers' Readiness to Work with Technically Gifted Children. Modern Journal of Language Teaching Methods. Vol.7, Is.9. P.143-150.

[11] Galimullina E. Z., Ljubimova E. M., \& Sharafeeva L. R. (2017). Introduction of the robotics in education of children and youth. Turkish online journal of design art and communication. Vol.7, p. 738-744.

[12] Alfimova A.S. (2009). Elective course "Elements of discrete mathematics" as a means of in-field specialization of education in high schools of the natural-mathematical profile. Izvestiya VGPU. 2009. No.6. URL: https://cyberleninka.ru/article/n/elektivnyy-kurselementy-diskretnoy-matematiki-kak-sredstvo-vnutriprofilnoy-spetsializatsii-obucheniyav-starshih-klassah-estestvenno (accessed: 05.21.2020).

[13] Kondaurova I.K., Lapteva Yu.Yu. (2018). Summer math site for younger teens. Karelian Scientific Journal. Vol. 7. № 2 (23). Pp. 30-34.

[14] Makhometa T.M., \& Tiahai I.M. (2018). Використання інтерактивного навчання у процесі підготовки майбутніх учителів математики. Балканско научно обозрение. № 1. Pp. 48-52.

[15] Starkey, P., Klein, A., and Wakeley, A. (2004). Enhancing young children's mathematical knowledge through a pre-kindergarten mathematics intervention. Early Child. Res. Q. 19, 99-120.doi:10.1016/j.ecresq.2004.01.002.-URL:

http://top-technologies.ru/ru/article/view?id=34048 (date of access: 01.03.2020). https://doi.org/10.1016/j.ecresq.2004.01.002

[16] Bryant, D. P., Bryant, B. R., Gersten, R., Scammacca, N., and Chavez, M. M. (2008). Mathematics intervention for first- and second-grade students with mathematics difficulties the effects of tier 2 intervention delivered as booster lessons. Remed. Spec. Educ. 29, 20-32. https://doi.org/10.1177/0741932507309712

[17] Dowker, A., and Sigley, G. (2010). "Targeted interventions for children with arithmetical difficulties," in Number 7-Understanding Number Development and Difficulties, BJEP Monograph Series II, vol. 65 (Leicester: British Psychological Society), 65-81. https://doi.org/10.1348/97818543370009x12583699332492

[18] Ehlert, A., and Fritz, A. (2013). Evaluation of maths training programme for children with learning difficulties. South Afr. J. Childhood Educ. 3, 117-140. https://doi.org/ $\underline{10.4102 / \text { sajce.v3i1.34 }}$

[19] Holmes, W., and Dowker, A. (2013). Catch Up Numeracy: a targeted intervention for children who are low-attaining in mathematics. Res. Math. Educ. 15, 249-265. https://doi.org/10.1080/14794802.2013.803779

[20] Schacter, J., and Jo, B. (2016). Improving low-income preschooler's mathematics achievement with Math Shelf, a preschool tablet computer curriculum. Comput. Human Behav. 55, 223-229. https://doi.org/10.1016/j.chb.2015.09.013

[21] Yoon, I. (2020). Developing a course to choose an engineering major at colleges with a pre-engineering program only. International Journal of Engineering Pedagogy, 10(4), 6992. https://doi.org/10.3991/ijep.v10i4.12987

[22] Overview of digital labs.URL: https://sitimedia.ru/cifrovye_laboratorii

[23] Digital laboratory Archimedes 4.0. Laboratory work in chemistry. Translation and publication in Russian. M.: Institute of New Technologies, 2010. -64 p. 
[24] Antipov S.A., \& Shinkareva T.E. (2011). The experience of using new digital technologies in the organization of students' research activities in ecology. Bulletin of the Voronezh State University, Series: Geography. 202 Geoecology, 2011, No. 2. P. 201-203

[25] Saenko, N., Voronkova, O., Volk, M., \& Voroshilova, O. (2019). The social responsibility of a scientist: Philosophical aspect of contemporary discussions. Journal of Social Studies Education Research, 10(3), 332-345.

[26] Köpeczi-Bócz, T. (2020). Learning portfolios and proactive learning in higher education pedagogy. International Journal of Engineering Pedagogy, 10(5), 34-48. https://doi.org/10.3991/ijep.v10i5.13793

[27] Burkova E.A. (2016). The use of digital laboratories in the classroom "Young Pharmacologists": Methodological materials. - Yoshkar-Ola: GBU DPO of the Republic of Mari El "Mari Institute of Education". 24 p.

[28] Quezada, V. D. (2020). Difficulties and performance in mathematics competences: Solving problems with derivatives. International Journal of Engineering Pedagogy, 10(4), 3553. https://doi.org/10.3991/ijep.v10i4.12473

[29] Gorovaya, M. M., Khanmurzina, R. R., Malakhova, L. A., Tagirova, N. P., Saenko, N. R. Shnyakina, E. Y., \& Zatsepina, M. B. (2017). Didactic principles of university information educational systems designing. Eurasian Journal of Analytical Chemistry, 12(7), 12011210. https://doi.org/10.12973/ejac.2017.00245a

[30] Lozovenko S.V. (2018). Laboratory workshop in physics using the digital laboratory Vernier. M: Ilexa.135 p.

[31] Petrova M.A. (2008). The use of digital laboratories in an educational physics experiment in a comprehensive school: the dissertation of the candidate of pedagogical sciences. M., $268 \mathrm{p}$.

[32] Johnsonbaugh R. (2008). Discrete Mathematics. 7th edition. Prentice Hall, 2008.

[33] Nevidomskaya I.A., Kopylova E.P., Sotnikova Yu.D., \& Nivinskaya S.I. (2014). The use of discrete mathematics in solving problems of economic content. Modern high technology. № 5-2. Pp. 169-171;

[34] Grafoanalizator: - environment for working with graphs. [website]. URL: http://grafoanalizator.unick-soft.ru/

[35] Klimina N.V. (2016). We solve problems with the help of graphs in the program "Graphical analyzer". Computer science at school. №6.

[36] Yeh, C.Y.C., Cheng, H.N.H., \& Chen, Z. (2019). Enhancing achievement and interest in mathematics learning through Math-Island. RPTEL 14, 5 URL: https://doi.org/10.1186/ s41039-019-0100-9

[37] Korableva, O., Durand, T., Kalimullina, O., \& Stepanova, I. (2019). Studying user satisfaction with the MOOC platform interfaces using the example of coursera and open education platforms. Paper presented at the ACM International Conference Proceeding Series, 26-30. doi: $10.1145 / 3322134.3322139$

[38] Gamage, D., Perera, I., \& Fernando, S. (2020). Exploring MOOC user behaviors beyond platforms. International Journal of Emerging Technologies in Learning, 15(8), 161-179. doi:10.3991/IJET.V15I08.12493

[39] Vodopyan G.M. (1998). Computer lab for subjects of the natural mathematical cycle // KIO. 1998. No. 1. - URL: https://cyberleninka.ru/article/n/kompyuternaya-laboratoriyadlya-predmetov-estestvenno-matematicheskogo-tsikla (date of access: 26.04.2020).

[40] Shadrin V.Yu. (2012). Additional education as a factor in the development of mathematical giftedness of a teenager in the conditions of a summer physical and mathematical school. Bulletin of Moscow State Regional University. Series: pedagogy. Issue. 1, p. 148153. 
[41] Kondaurova I.K., Kulikova N.S. (2019). The system of classes in mathematics for participants in the camp educational shift. ANI: pedagogy and psychology. №3 (28). URL: https://cyberleninka.ru/article/n/sistema-zanyatiy-po-matematike-dlya-uchastnikovlagernoy-obrazovatelnoy-smeny

[42] Vasilenko, E., Vasilenko, P., Saenko, N., Borysov, V., Borysova, S., \& Prodan, I. (2020). Engineering aspect of modern concept of professional education of artists and designers in academic figure. International Journal of Engineering Research and Technology, 13(11), 3625-3630.

\section{Authors}

T. I. Anisimova is the Head of the Department of Mathematics and Applied Informatics of the Yelabuga Institute of KFU, Candidate of Pedagogical Sciences, Associate Professor. Email: anistat@mail.ru.

A. R. Ganeeva is Candidate of Pedagogical Sciences, Associate Professor of the Department of Mathematics and Applied Informatics of the Yelabuga Institute of KFU. Email: aigul_ganeeva@mail.ru.

L. R. Sharafeeva is Senior Teacher of the Department of Mathematics and Applied Informatics of the Yelabuga Institute of KFU. Email: shlandysh@yandex.ru.

Article submitted 2020-08-03. Resubmitted 2020-10-31. Final acceptance 2020-11-01. Final version published as submitted by the authors. 